\title{
Otizm Spektrum Bozukluğu Olan Çocuklara Yönelik Hayvan Destekli Müdahalelerle Yürütülen Araştırmaların İncelenmesi
}

\section{A Review of Studies Conducted with Animal Assisted Interventions for Children with Autism Spectrum Disorder}

\author{
Damla Çetin ' (D), Selmin Çuhadar' (D)
}

\section{$\ddot{0 z}$}

Bu çalışmanın amacı, 2000-2019 yılları arasında otizm spektrum bozukluğu olan çocuklara hayvan destekli müdahaleler aracilığılla sunulan uygulamaların etkisini tek- denekli araştırma modelleriyle sınayan çalışmaları demografik, yöntemsel ve bulgu değişkenleri açısından incelemektir. Bu bağlamda yapılan alanyazın taramasında dâhil etme ve hâriç tutma kriterlerini karşılayan 11 makale incelemeye alınmış ve betimsel olarak analiz edilmiştir. Analiz sonucunda, bir çalışma dışında tüm çalışmalarda kullanılan hayvan destekli müdahalenin otizm spektrum bozukluğu olan katılımcıların hedef becerilerinde olumlu etki yarattığı ve gelişim sağladığı tespit edilmiştir. Ancak, araştırmaların çoğunun $A B$ ve $A B A$ modeli gibi en temel ve deneysel kontrol açııından zayıf olarak nitelendirilen tek- denekli araştırma modelleri ile desenlendiği ve bazı araştırmaların yinelenebilir özellikte raporlanmadığı belirlenmiş̧tir. Bu doğrultuda hayvan destekli müdahalelerin etkilerini sınayan, katılımcı özellikleri, başlama düzeyi ve uygulama evrelerinin daha ayrıntılı ve açık bir biçimde rapor edildiği yinelenebilir özellikte daha fazla sayıda araştırmaya gereksinim olduğu düşünülmektedir.

Anahtar sözcükler: 0tizm, otizm spektrum bozukluğu, hayvan destekli aktivite, hayvan destekli terapi, hayvan destekli müdahale

\section{Abstract}

The aim of this study is to examine the studies' effects of the practices offered through animal assisted interventions to children with autism spectrum disorder between 2000 and 2019 in terms of demographic, methodological and results variables. In this context, 11 articles meeting the inclusion and exclusion criteria were reviewed and analyzed descriptively. As a result of the analysis, it was determined that the animal assisted interventions used in all studies except one study had a positive effect on the target skills of the participants with autism spectrum disorder and provided improvement. However, it was determined that most of the studies were designed with single-subject research models such as the $A B$ and $A B A$ models, which were considered to be weak in terms of the most basic and experimental control, and some studies were not reported as reproducible. In this respect, it is thought that more reproducible studies are needed to test the effects of animal assisted interventions, and to report the participant characteristics, baseline and implementation phases in more detail and clearly.

Keywords: Autism, autism spectrum disorder, animal assisted activity, animal assisted therapy, animal assisted treatment

'Trakya Üniversitesi, Edirne, Türkiye

$凶$ Damla Çetin, Trakya Üniversitesi, Edirne, Türkiye

damlacetin2@trakya.edu.tr|0000-0002-0597-6278

Geliş tarihi/Received: 15.12 .2020 | Kabul tarihi/Accepted: 10.04.2021 | Çevrimiçi yayın/Published online: 03.06.2021 
INSSAN-HAYVAN etkileşimini destekleyen kurama göre insan-hayvan etkileşimi olumlu, fiziksel ve psikolojik sonuçlar doğurmaktadır. Bu kuram insanların hayvanları, yargılamayan sosyal etkileşim eşi olarak gördüklerini ileri sürer [Tohum Otizm Vakfı (TOV) 2019]. Hayvanlarla etkileşimin belgelenmiş faydaları arasında; evcil bir hayvana sahip olmanın, özellikle o hayvanla yapilan fiziksel aktivitelerin insanlara kendilerini iyi hissettirdiği ve bazıları önleyici, bazıları iyileştirici olmak üzere pek çok olumlu etkisi olduğunu göstermektedir (Nimer ve Lundahl 2007, VanFleet ve Faa-Thompson 2010, O'haire 2013, Davis ve ark. 2015, Fine 2015, Hajar 2015, Mey 2017, TOV 2019). Bu olumlu etkilerin yanı sıra evcil hayvanlar, yalnızlı̆̆ı hafifletme, stres, kaygı ve depresyonu azaltma, sosyal etkileşimi, egzersiz ve eğlenceyi teşvik etme, koşulsuz sevgi ve şefkat sağlamaktadırlar (Jessen ve ark. 1996, Headey 1999, Morrison 2007).

Hayvanlarla etkileşimin yararlı etkileri hem tarihsel hem de güncel araştırmalar ile belgelenmiş ve bu araştırmalar Morrison (2007) ile Purewal ve arkadaşlarının (2017) çalı̧malarında incelenmiştir. Küçük yaşta evde hayvan besleyen çocukların sosyal becerilerinin daha güçlü olduğuna ilişkin bulgulara ek olarak, araştırmalar bir hayvana bakmanın çocukların daha aktif ve güvenli büyümelerine yardımcı olduğunu, yaşlılar ve yetişkinler içinse değerli arkadaşlıklar sağlayabildiğini göstermektedir (Mey 2017, Purewal ve ark.2017, Wanser ve ark.2019, Human Animal Bond Research Institute(HABRI) 2020). Öyle ki sadece hayvan faaliyetlerini izlemenin, hayvanlarla oynamanın, onları sevmenin ya da okşamanın bile kortizol seviyesini düşürdüğü, serotonin üretimini artırarak stresi azaltıcı etki gösterdiği belirlenmiştir (Centers for Disease Control \& Prevention, House \& Landis 1988, Serpell 1991, McNicholas ve ark. 2005, Wells 2011, Barton ve Behravesh 2017, National Institutes of Health (NIH) 2018, National Center for Emerging \& Zoonotic Infectious Diseases (NCEZID) 2019, Casciotti ve Zuckerman 2020, HABRI 2020). Araştırma sonuçları evcil hayvan sahiplerinin evcil hayvanı olmayanlara göre daha düşük kan basıncı ve kalp hızına sahip oldukları ve hipertansiyonu olan kişilerin, köpeklerini severken tansiyonlarının düştüğünü göstermektedir (Allen ve ark. 2002, Wright ve ark. 2007, Levine ve ark. 2013). Qureshi ve ark.'nın (2009) 2,400 kedi sahibi ile yürüttüğü araştırma sonucunda kedi sahiplerinin, kedi sahibi olmayan insanlara göre kardiyak hastalık nedeniyle ölme risklerinin daha düşük olduğu saptanmıştır. Araştırmalar köpek veya kedi olan bir evde büyüyen çocukların alerjik reaksiyonlara hassasiyet ihtimalinin daha düşük olduğunu da göstermiştir (Hasselmar ve ark. 1999, Remes ve ark. 2001, McNicholas ve ark. 2005, Lodge ve Grace 2012, Hajar 2015, NIH 2018, Casciotti ve Zuckerman 2020, HABRI 2020). Tüm bu olumlu etkileri ortaya koyan araştırma sonuçlarına paralel olarak, giderek artan bir oranda özel eğitimli hayvanları eğitim kurumlarına (Delta Society 2019), hastanelere, bakım evlerine vb. ortamlara getirmek için çalışmalar yapılmaktadır (Barak ve ark. 2001, Edwards ve Beck 2002, Serpell 2006, Friedmann ve Son 2009, Wells 2009, Hajar 2015).

Hayvanların terapötik (iyileştirici/tedavi edici) aktivitelere dâhil edilmesi, hem hayvan destekli terapi (animal-assisted therapy) hem de hayvan destekli aktiviteleri (animalassisted activities) kapsayan daha genel bir ifade altında "Hayvan Destekli Müdahale 
(Animal-Assisted Intervention-AAI)" toplanmaktadır (Kruger ve Serpell 2010, Griffin ve ark. 2011, Karayağız-Muslu ve Conk 2011, O’Haire 2013). Terim ve tanımlamalardaki farklılıklar karışıklığa yol açmaktadır. Bu nedenle Avustralya'da tedavi hayvanlarının sertifikasyonundan sorumlu en büyük organizasyon olan Delta Birliği (Delta Society) terminolojide standardizasyon sağlamak için "hayvan destekli tedavi”, "hayvan destekli aktivite" ve "hayvan destekli müdahaleleri" şu şekilde tanımlamıştır. Hayvan Destekli Terapi (HDT), belli kriterlere uygun bir hayvanın sürecin bir parçası olarak tedaviye katıldığı, hedefe yönelik girişimlerdir. Hayvan destekli tedaviler bu alanda uzmanlaşmı̧̧ profesyonel kişiler tarafından yönlendirilmekte ya da uygulanmaktadır (Delta Society 2009). Hayvan Destekli Aktiviteler (HDA) ise, yaşam kalitesini artırmak, eğitim, eğlence ve/veya motivasyonel terapötik yararlar için firsatlar sunan faaliyetlerdir. Hayvan destekli aktivitelerin temel özellikleri; belli tedavi hedeflerinin olmaması, gönüllülük esasına göre olması ve ziyaretin spontane olmasıdır. Özel eğitimli profesyoneller, paraprofesyoneller ve/veya gönüllüler ile uygulanmaktadır (Delta Society 2009). Hayvan Destekli Müdahale (HDM), insanlarda terapötik kazanımlar amacıyla kasıtlı olarak sağlık, eğitim ve insan hizmetlerine hayvanları dâhil eden hedefe yönelik bir müdahaledir. Başka bir ifadeyle HDM, tedavi sürecinin bir parçasına bilinçli olarak hayvanların katılmasıdır. HDM, HDT veya Hayvan Destekli Eğitim gibi resmî insan hizmetlerinde insan-hayvan ekiplerini biraraya getirmektedir.

Araştırmalar, çocukların hayvanlarla etkileşimlerinin psikolojik (Odendaal 2000), duygusal, sosyal (Zasloff ve ark. 1999, Anderson ve Olson 2006, Walters ve ark. 2008) yararlarının yanı sıra, çocukların saldırgan ve uygun olmayan davranışlarının azaltılmasında (Katcher ve Wilkins 1998) ve fiziksel sağlıkları üzerinde (Gee Harris ve Johnson 2007) olumlu etkilerinin olduğunu göstermiştir. HDM'nin çocuklarda kullanımı konusunda yürütülmüş olan çalışmalar dikkat eksikliği ve hiperaktivite bozukluğu, duygu ve davranış bozukluğu, dil ve konuşma bozuklukları, öğrenme güçlüğü, serebral palsi, psikiyatrik sorunlar, gelişim geriliği ve süreğen hastalığ olan çocuklar ve otizm spektrum bozukluğu (OSB) üzerine odaklanmıştır (Karayağız-Muslu ve Conk 2011, O’Haire 2013). Son zamanlarda, OSB olan çocukların eğitimlerinde ve günlük yaşamlarında HDM'den yaralanabileceği konusuna dikkat çekilmektedir (Esposito 2011, Jenkins ve Reed 2013, O’Haire 2013). Tablo 1'de hayvanlarla etkileşimin OSB olan çocuklar için fayda sağladığı alanlar ve etkileri özetlenmiştir.

Amerikan Ulusal Otizm Merkezi [National Autism Center (NAC)] tarafindan 2015 yılında yayınlanmış olan raporda da OSB tanısı almış çocuğa sahip olan bazı ailelerin HDM'yi bir seçenek olarak görebildikleri rapor edilmiştir (NAC 2015). HDM'nin atlar, yunuslar ve köpekler kullanılarak uygulanan, özellikle gelişimsel yetersizliği olan bireyler için kullanılmaya başlandığı belirtilmiştir. HDM, farklı disiplinler tarafindan farklı amaçlarla kullanılmaktadır. Ancak uygulamanın OSB olan çocuklarla çalışan eğitimcilere, uzmanlara ve ailelere önerilebilmesi için HDM'yi konu alan araştırmalardan elde edilecek olumlu bulgulara dolayısıyla HDM'nin etkilerini ortaya koyan yeterli sayıda ve yinelenebilir nitelikte araştırmalara ihtiyaç duyulmaktadır. 
Tablo 1. Hayvanlarla Etkileşimin OSB için fayda sağladığı alanlar ve etkileri

\begin{tabular}{|c|c|}
\hline $\begin{array}{l}\text { Fayda sağlanan } \\
\text { alanlar }\end{array}$ & Etkiler \\
\hline $\begin{array}{l}\text { Fiziksel, duygusal ve } \\
\text { psikolojik }\end{array}$ & $\begin{array}{l}\text { OSB olan çocukların hayvanlarla etkileşimleri fiziksel ağrı algııını, kan basıncııı, kalp hızını, anksiyeteyi, } \\
\text { depresyonu, kortizol seviyesini ve yalızılık duygusunu azaltıcı etki sağlayabilir. Ayrıca hayvanlar } \\
\text { heyecan, sevinç, üzüntü gibi insan duygularını hissedebilirken, otizmli bireyler bu duyguları başkalarında } \\
\text { algılayamayabilir. Bu açıdan bakıı dığında, bir hayvanla temas ve etkileşime girme otizmli bireylerin duyguları } \\
\text { anlamalarına ve başkalarına aktarabilmelerine yardımcı olabilir. }\end{array}$ \\
\hline Sosyal etkileşim & $\begin{array}{l}\text { Hayvanlar, OSB olan çocuklara sosyal iletişim kanalı sağlayarak çocukların başkalarıyla iletişim kurma arzusunu } \\
\text { ve yeteneğini artırabilir. Hayvanların varlığı ile çocukların kendilerini sosyal ortamdan izole etme davranışları } \\
\text { azalarak sosyal davranışlarında artış sağlanabilir. }\end{array}$ \\
\hline Teşvik & $\begin{array}{l}\text { Hayvanlar OSB ile ilişkili duyusal ve duygusal uyarılma seviyelerine karşı koyan güçlü ve çoklu duyu uyaranı } \\
\text { sundukları için otizmli çocuklarda dikkatin polarizasyonunu sağlayabilir. }\end{array}$ \\
\hline Koruma & $\begin{array}{l}\text { OSB olan çocuklar kendilerini tehlikeye sokacak ve ailelerde stres yaratacak öngörülemeyen davranışlarda } \\
\text { bulunabilirler. Ancak hayvanlar, bu gibi davranışlarda koruyucu rol üstlenerek çocuğun davranışına karşı } \\
\text { koyabilir. Örneğin; evinden uzaklaşma veya yoğun trafiğe çıkma gibi davranışlarda köpekler çocuğun bu } \\
\text { davranışlarına karşı koyarak hem çocuğu koruyucu rol üstlenmiş olurlar hem de uyguladığı karşı koyma gücü ile } \\
\text { ailelerin durumu fark edip müdahale etmelerine zaman tanımış olurlar. }\end{array}$ \\
\hline Kendi kendine yardım & $\begin{array}{l}\text { Hayvanlarla oynanan oyunlar, hayvanın bakımı-evcilleştirilmesi gibi etkileşimler, otizmli çocukların motor } \\
\text { becerilerinde ve günlük yaşamda kendilerine yönelik ihtiyaçlarını karşılamalarında gelişme sağlayabilir. } \\
\text { Örneğin; köpeği evcilleştirme süreci, çocuklarda kaptan yiyeceği boşaltma veya boşalan kaba su tutma gibi } \\
\text { beceriler kazandırabilir. }\end{array}$ \\
\hline Konuşma ve iletişim & $\begin{array}{l}\text { Hayvanların varlığı ortamdaki fiziksel uyarılmayı azaltarak açık-tutarlı sözsüz iletişim ipuçları sağlayabilir. } \\
\text { Böylece OSB olan çocukların uyarıııları yorumlayabilme düzeyi ve uyumları artar. }\end{array}$ \\
\hline Motivasyon ve katilım & $\begin{array}{l}\text { Hayvanlar ilham verme ve motive etme yeteneğine sahiptirler. Köpekler koşulsuz sevgi sunmaları ve yargılayıı } \\
\text { olmadıkları için otizmli çocukların motivasyonunu artııcı etki gösterebilirler. Özellikle hayvan destekli } \\
\text { tedavilerde hastanın motivasyonunu artırarak tedavi sürecine katıımını sağlayabilirler. }\end{array}$ \\
\hline Arkadaşlık & $\begin{array}{l}\text { OSB olan çocukların hayvanlarla etkileşimleri ve hayvanın bakımında rol üstlenmeleri çocuklarda güvenme, } \\
\text { yardım etme, saygılı ve sorumlu olma gibi özellikleri içeren sağlıkı karakter gelişiminin temelini destekler. Aynı } \\
\text { zamanda otizmli çocuklardaki yalnızık duygusunun azaltılmasını sağlayabilir. }\end{array}$ \\
\hline
\end{tabular}

Uyarlandığı kaynak Mey 2017

Alanyazında yapılan çalı̧̧malar incelendiğinde; O’Haire (2013), Davis ve arkadaşları (2015), Srinivasan ve arkadaşları (2018), Dimolareva ve Dunn (2020), hayvan destekli uygulamaların OSB olan bireylerdeki etkisini araştıran çalışmaları incelemişlerdir. O'Haire (2013), hakemli dergilerde yayınlanan 14 çalışmayı incelemiş, çalışma sonuçlarında OSB olan bireylerde artan sosyal etkileşim ve iletişim sağladığını, katılımcıların problem davranışlarında ve stres seviyelerinde azalmaya yol açtığını, ancak çalışmaların birçok metodolojik zayıflıkla sınırlı olduğunu, daha ayrıntılı ve titiz araştırmaların yapılması gerektiğini vurgulamıştır. Davis ve arkadaşları (2015) katılımcı özellikleri, bağımlı-bağımsız değişkenler, çalışma sonuçları ve kanıt kesinliği açısından 20 çalışmayı değerlendirerek çalışmaların olumlu ya da karışı sonuçlar rapor ettiklerini, literatürde metodolojik kusur olduğunu bunun da müdahale etkinliğini belirlerken endişeye neden olarak ek sorgulama ihtiyacı doğurduğunu belirtmiştir. Srinivasan ve arkadaşları (2018) ise OSB olan bireylerde at terapisinin etkilerini test eden çalışmaları incelemiş ve inceleme sonucunda; at terapisinin OSB olan bireylerde davranış becerileri ile bir dereceye kadar sosyal iletişim üzerinde olumlu etkileri olduğunu 
ancak, proprioseptif duyu (vücudumuzun pozisyonu ve hareketlerimiz hakkındaki gerekli bilgiyi beynimize veren duyu sistemi- özduyum), bilişsel ve fonksiyonel beceriler üzerindeki olumlu etkilerine yönelik kanıtların sınırlı olduğunu belirtmiştir. Dimolareva ve Dunn (2020) ise, OSB tanısı almış toplamda 489 katılımcının oluşturduğu 16 çalışmayı ulaşılan terapötik değerler açısından değerlendirmişler; HDM'nin OSB olan katılımcılarda sosyal etkileşim ve iletişimdeki gelişmeler ile OSB semptomlarında azalmaya yönelik etki boyutunun küçük olduğunu, dolayısıyla HDM'nin OSB olan çocuklar için sosyal etkileşim ve iletişimde küçük gelişmeler sağladığını saptamışlardır. OSB olan bireylerde hayvan destekli uygulamaların etkileri konusunda Türkiye'de yapılmı̧ bir araştırmaya ise henüz rastlanmamıştır. Hayvan destekli uygulamalarla ilgili Türkiye'deki çalışmalar yalnızca konu ile ilgili açıklamaya dayalı, bilgi verme amaçlıdır. Bunlar; Cevizci ve arkadaşları (2009a, 2009 b), Karayağız-Muslu ve Conk (2011), Özkul (2014), Elitok (2017), Akkuş ve arkadaşları (2018), Demiralay ve Keser (2019), Çakıcı ve Kök’ün (2020) çalışmalarıdır.

Türkiye'de eğitimde HDM kullanımı konusunda yapılan tek çalışma; özellikle özel eğitim ihtiyacı olan kişilerle çalı̧̧an öğretmenleri ve eğitim alanındaki diğer profesyonelleri hayvanların eğitime entegrasyonu konusunda eğitmeyi amaçlayan, 2015-2017 yılları arasında yürütülen "Animal Integration in the Educational Programme - ZORO (Ĕgitime Hayvan Entegrasyonu Kilavuz Kitab1)” isimli uluslararası Erasmus + Projesidir. HDM'nin OSB olan bireylerde kullanımının etkilerini araştıran bir çalışma bulunmamaktadır. Alanyazında da özellikle 2019'dan sonra yapılan çalışmalarda büyük artış olduğu görülmektedir. Ancak HDM'nin etkilerini araştıran mevcut çalışmalarda da yöntemsel yetersizlikler olduğu görülmektedir. Uygulamanın bilimsel dayanaklı uygulamalar kategorisinde olabilmesi için daha fazla araştırma grubu tarafından ve yöntemsel yönden daha yinelenebilir araştırmaların yapılması gerekmektedir. Özellikle son yıllarda çalışmalarda artı̧̧ (Akkuş ve ark. 2018, Souza-Santos ve ark. 2018, Demiralay ve Keser 2019, Kwon ve ark. 2019, Pan ve ark. 2019, Çakıcı ve Kök 2020, Dimolareva ve Dunn 2020) olduğu görülse de OSB olan çocuklarda HDM'nin kullanımını ve etkilerini araştıran, ileriki araştırmalara yol gösterecek ve yinelenmeye uygun metodolojik özellikler sunabilen tek-denekli araştırmalarla şekillendirilmiş çalışmaların incelenmesi, var olan durumun ortaya koyulması gerektiği düşünülmüştür. Tek-denekli araştırmalar standart şartlarda yinelenen ölçümler yapılarak her katılımcının kendi kontrolünü oluşturması ile davranış değiştirmeye veya öğretim uygulamalarının etkililiğini ortaya koymaya olanak sunan araştırmalardır (Tekin-İftar 2018). Horner ve arkadaşları (2005), tek-denekli araştırma modellerinin özel gereksinimli bireyeler ve onların aileleri için özel eğitim alanındaki uygulamaları geliştirmek amacıyla kullanılan önemli ve güçlü modeller olduğunu ifade etmişlerdir. Özel gereksinimli bireyeler gibi istisnai gruplara yönelik müdahaleleri incelemeye olanak sağlayan bu modeller aynı zamanda özel eğitim uygulamalarını geliştirebilecek kanıta dayalı sonuçların ortaya koyulmasını da sağlayabilmektedirler.

Bu nedenle bu çalışmada, OSB olan çocuklara HDM'nin etkisini tek-denekli araştırma modelleriyle sınayan çalışmaların demografik, yöntemsel ve bulgu değişkenleri açısından incelenerek kapsamlı bir betimsel analiz yapılması amaçlanmışır. Tarama aşamasında 2000 
y1lı öncesinde, hayvan destekli müdahalelerin OSB olan bireylerde etkisini inceleyen ve tek- denekli araştırma yöntemlerinden biri ile desenlenmiş yalnızca bir çalışma bulunmuş ancak; tam metin erişime açık olmadığından dolayı 2000 yılı başlangıç olarak kabul edilmiş; araştırmanın raporlaştırma sürecine 2019 yılında başlanmış olması nedeniyle de dâhil edilen çalışmalar 2019 yılı ile sonlandırılmıştır. Araştırmanın amacına bağlı olarak izleyen sorulara yanıt aranmıştır: (a) Katılımcıların özellikleri (yaş, cinsiyet, zekâ puanı, yetersizlik türü, problem davranışlar) nelerdir? (b) Sunulan müdahalelerde hangi becerilerin öğretimi hedeflenmiştir? (c) Çalışmalar hangi tek-denekli araştırma modelleri ile desenlenmiştir? (d) Araştırmalar genel olarak nerede, kimler tarafından ve ne kadar süre ile gerçekleştirilmiştir? (e) Çalı̧̧malarda kullanılan hayvanların özellikleri nelerdir? (f) Çalışmalarda izleme, genelleme, uygulama güvenirliği/gözlemciler arası güvenirlik ve sosyal geçerliğe ilişkin bulgular nelerdir? (g) Araştırmalardan elde edilen etkililik bulguları ne yönde sonuçlanmıştır?

\section{Yöntem}

\section{Alanyazın tarama süreci}

Makalelerin belirlenmesinde iki aşama izlenmiştir. İlk aşamada "Trakya Üniversitesi Kütüphane Veri Tabanları Toplu Tarama” sistemleri üzerinden EBSCO, Elsevier, Springer, Sage Journals, TR Dizin, Sobiad, ASOS gibi elektronik veri tabanları taranmıştır. Arama yapilirken "Animal Assisted and Autism”, "Animal Assisted Invertion" "Animal Assisted Intervention and Autism" anahtar kelimeleri kullanılmış ve 65 sonuç listelenmiştir. Çıkan 65 sonuçtan tam metin olarak erişime açık olan 27 makaleye ulaşılmıştır. 27 makaleden üç tanesi derleme, 16 tanesi deneysel çalı̧̧ma iken sekiz tanesi tek-denekli araştırma yöntemleri ile desenlenen çalışmalar olup bunlar araştırmaya dâhil edilmiştir. İkinci aşamada ulaşılan 27 makalenin kaynakçaları da taranarak tek-denekli araştırma deseni ile yürütülmüş olan makaleler tespit edilmiş ve ilk adımda yapılan taramada ulaşılamayan makalelere Google Scholar üzerinden tarama yapılarak ulaşılmıştır. Tam metin erişime açık olan tek-denekli araştırma modelleri ile desenlenen üç makaleye daha erişim sağlanmıştır. Sonuç olarak, tam metin erişime açık ve tek-denekli araştırma modellleri ile desenlenmiş 11 makaleye erişim sağlanmış ve araştırmaya dâhil edilmiştir. Şema 1'de tarama süreci verilmiştir.

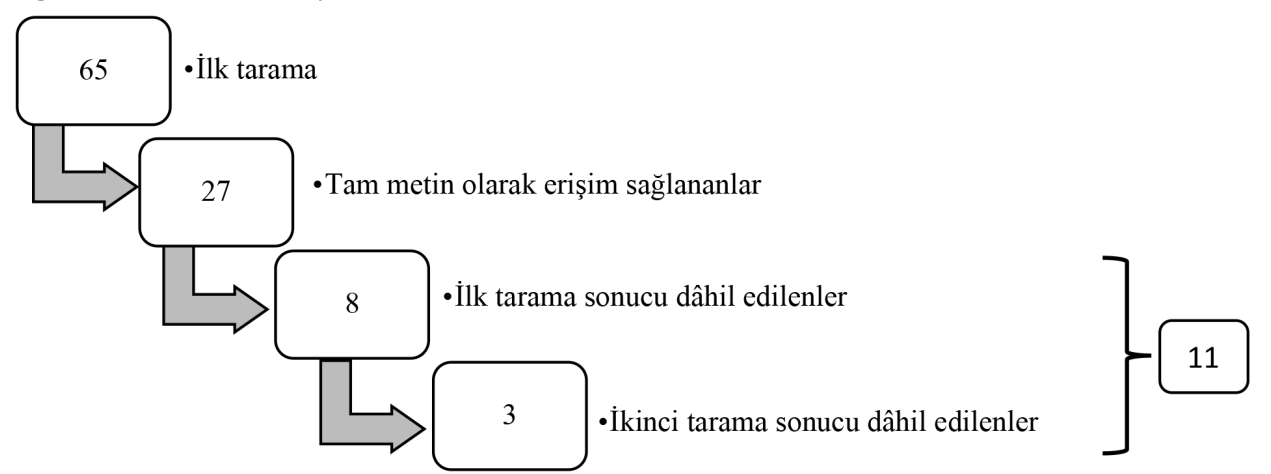

\section{Şema 1. Alanyazın tarama süreci}




\section{Dahil etme ve hariç tutma kriterleri}

Makalelerin araştırmaya dâhil edilmesinde dikkate alınan ölçütler şunlardır: Araştırmaların 2000-2019 yılları arasında yayımlanmı̧s olması, İngilizce ve Türkçe dillerinden biriyle yayımlanmış olması, hakemli dergilerde yayımlanmış olması, tek-denekli araştırma modelleri ile desenlenmiş olması, katılımcıların OSB tanılarının olması (OSB ile birlikte ek engele sahip olanlar da dâhil edilmiştir). 2000 yılı öncesinde, hayvan destekli müdahalelerin OSB olan bireylerde etkisini inceleyen ve tek-denekli araştırma yöntemlerinden biri ile desenlenmiş yalnızca bir çalışma erişilebilmiştir. Ancak; araştırmanın tam metin erişime açık olmaması nedeniyle 2000'li yıllar başlangıç olmak üzere alanyazında görünürlüğü giderek artan HDM konu alan araştırmalar için başlangıç yılı olarak 2000 yılı tercih edilmiştir. Araştırmanın raporlaştırma sürecinin 2019 yılında başlanmış olması nedeniyle dâhil edilen çalışmalar 2019 yılı ile sonlandırılmıştır. Dahil edilen çalışmalardaki katılımcılardan DSM5 öncesi tanılama alanlar olduğu için DSM-5'de tek çatı altında OSB adıyla birleştirilen Yaygın Gelişimsel Bozukluk, Otistik Bozukluk, Asperger Sendromu, Rett Sendromu, Çocukluk Dezintegratif Bozukluğu ve Başka Türlü Adlandırılamayan Yaygın Gelişimsel Bozukluk tanıları, incelenen çalışmada yer alan ismiyle belirtilmiştir.

Makalelerin hariç tutulmasında dikkate alınan ölçütler ise şunlardır: Araştırmaların tek-denekli araştırma yöntemlerinden biri ile desenlenmiş olmaması, araştırmanın gerçek terapi hayvanı ile değil; simülasyon, hayvan figürlü oyuncak, robot vb. ile yürütülmesi. Dahil etme ve hariç tutma kriterlerine göre araştırma verilerini oluşturan 11 makale "Demografik Özelliklere İlişkin Bulgular, Yöntemsel Özelliklere İlişkin Bulgular” başlıklarına göre tablo haline getirilerek betimlenmiştir.

\section{Betimsel analiz süreci}

Belirlenen makaleler; yaş, sayı ve cinsiyet, tanı, zeka puanı, problem davranışlar olmak üzere demografik özellikler ve araştırma modeli, bağımlı değişken, bağımsız değişken, hayvan özellikleri, süre, ortam, uygulayıcı, sosyal geçerlik-kalıcılık-genelleme-güvenirlik, sonuç olmak üzere yöntemsel özellikler açısından değerlendirilmiştir. Değerlendirme sonuçları Tablo 2 ve Tablo 3'te yer almaktadir.

\section{Kodlayıcılar arası güvenirlik}

Makalelerin her biri betimsel analiz sürecinde yer verilen değişkenler açısından birinci yazar tarafindan okunarak değerlendirilmiştir. Betimsel analiz sürecinde ortaya çıkabilecek herhangi bir öznelliği ya da yanlılı̆̆ sürecine dâhil edilen ve birinci yazar tarafindan incelenen makalelerin yaklaşık olarak $\% 45,5$ ’ $\mathrm{i}$ $(\mathrm{n}=5)$ yansız atama yoluyla belirlenerek ikinci yazar tarafindan betimsel analiz sürecindeki kriterler açısından incelenmiştir. İki yazarın yaptığı kayıtlar üzerindeki sonuçların uyuşma düzeyi belirlenmiştir. Kodlayıcılar arası güvenirlik yaklaşık olarak \%88 bulunmuştur. Güvenirlik hesaplamasında, [görüş birliği/(görüş birliği + görüş ayrılığı) x 100] formülü kullanılmıştır (Wolery Bailey ve Sugai 1988). 
Tablo 2. Demografik özelliklere ilişkin bulgular

\begin{tabular}{|c|c|c|c|c|c|}
\hline Kaynak & Yaş & $\begin{array}{l}\text { Sayi- } \\
\text { cinsiyet }\end{array}$ & Tanı & Zeka puanı & Problem davranışlar \\
\hline Martin ve Farnum (2002) & $3-13$ & $10(2 \mathrm{~K} 8 \mathrm{E})$ & 7 YGB-2asperger-1 0SB & - & - \\
\hline Sams ve ark. (2006) & $7-13$ & $22(-)$ & OSB (+2 Serebral palsi) & - & - \\
\hline Kršková ve ark. (2010) & $7-13$ & 9 (4K 5E) & $\begin{array}{l}1 \text { Asperger - } 8 \\
\text { kanner+zihinsel engel }\end{array}$ & - & - \\
\hline Viau 2010 & $3-14$ & 42 (5K 37E) & $\begin{array}{l}34 \text { OSB ( } 2 \text { asperger- } 6 \\
\text { YGB) }\end{array}$ & - & - \\
\hline Silva ve ark. (2011) & 12 & $1(\mathrm{E})$ & OSB & - & Saldırgan davranışlar, kaygı \\
\hline Kern (2011) & $3-12$ & 24 (6K 18E) & OSB & - & - \\
\hline Jenkins ve Reed (2013) & $6-14$ & 7 (1K 6E) & OSB & - & $\begin{array}{l}\text { Ortam için uygun olmayan herhangi } \\
\text { bir yıkıcı davranış (örn. saldırganlık, } \\
\text { basmakalıp) sergileme }\end{array}$ \\
\hline Holm ve ark. (2014) & $6-8$ & $3(\mathrm{E})$ & OSB & - & $\begin{array}{l}\text { Yüz kaslarının gerilmesi, parmakların } \\
\text { kapanması, yüze vurma, burnu itme, } \\
\text { alkışlama, ekolali, ağzına nesne sokma }\end{array}$ \\
\hline Grigore ve Rusu (2014) & $7-8$ & $3(1 \mathrm{~K} 2 \mathrm{E})$ & OSB & $85-115$ & Ağlama, ekolali, yüksek ses \\
\hline Llambias ve ark. (2016) & $4-8$ & 7 (3K 4E) & $\mathrm{OSB}+2 \mathrm{DEHB}$ & - & - \\
\hline Fung (2017) & $8-10$ & $2(2 \mathrm{E})$ & OSB + zihinsel yetersizlik & - & - \\
\hline
\end{tabular}

K: Kız, E: Erkek, OSB: Otizm Spektrum Bozukluğu, YGB: Yaygın Gelişimsel Bozukluk, DEHB: Dikkat Eksikliği ve Hiperaktivite Bozukluğu Not: Makaleler yayın yılına göre geçmişten günümüze doğru sıralanmıştır. "+" işareti olarak belirtilenler OSB ile birlikte sahip olunan diğer yetersizlikleri ifade etmektedir.

\section{Bulgular}

OSB olan çocuklara hayvan destekli müdahalelerin etkisinin araştırıldığı 11 çalışmanın demografik, yöntemsel ve bulgu değişkenlerine ilişkin elde edilen bulgular izleyen başlıklar altında ayrıntılı olarak açıklanmaktadır.

\section{Demografik özellikler}

Demografik özelliklere ilişkin bulgular Tablo 2'de görüldüğü gibi katılımcı özellikleri açısından değerlendirilmiş ve tablodaki bilgiler özetlenmiştir. Katılımcı özellikleri analiz edilirken değişkenler yaş ve cinsiyet, sayı ve tanı, zekâ puanı ve problem davranışlar olmak üzere dört ayrı kategoride ele alınmıştır.

\section{Yaş ve cinsiyet}

Katılımcıların yaşları tüm çalışmalarda verilmiş; cinsiyetlerine ait bilgiler ise yalnızca bir çalışmada verilmemiştir. Katılımcıların yaş gruplarına göre dağılımları incelendiğinde 11 çalışmada da 3-14 yaş arasında katılımcıların olduğu görülmektedir. Cinsiyet açısından değerlendirildiğinde; cinsiyet bilgileri verilmeyen çalışma hâriç tutulduğunda diğer çalışmalara katılan toplam 108 katılımıının 22'sinin kız, 86'sının erkek olduğu görülmektedir. 


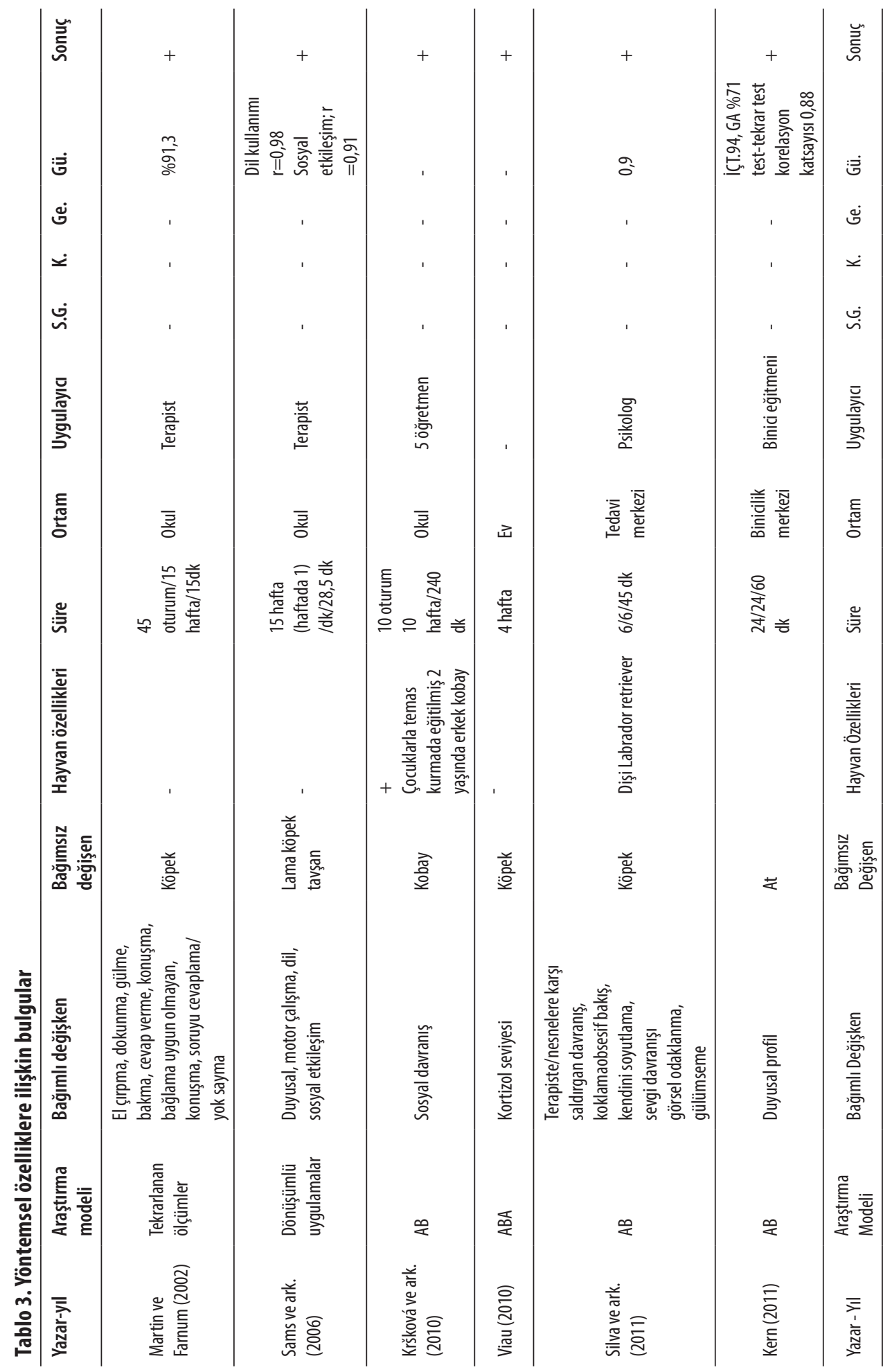




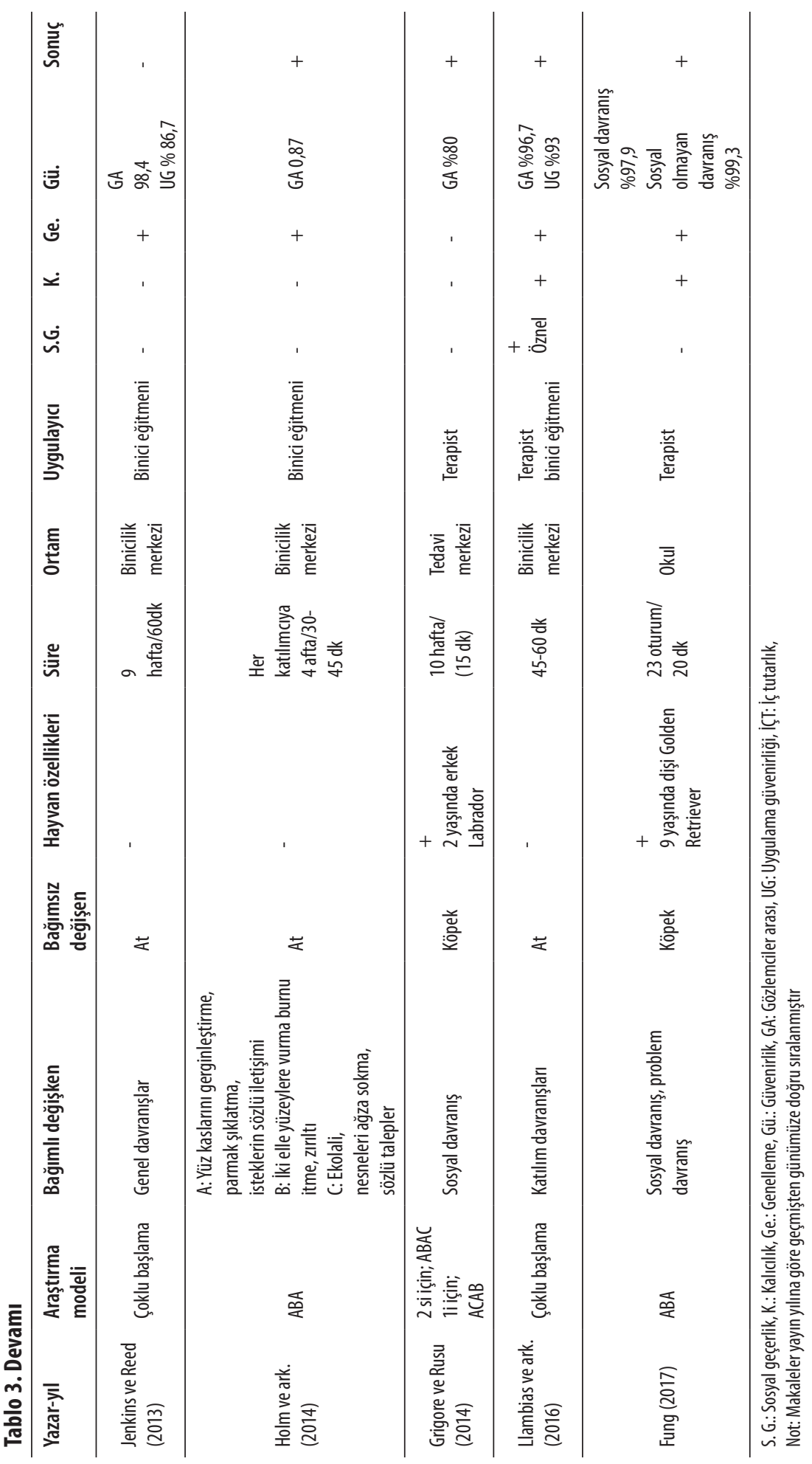




\section{Sayı ve tanı}

Çalışmaların dördünde katılımcı sayısı 1-3 arasında; üçünde 7-9 arasında; birinde 10; ikisinde 22-24 arasında, birinde ise 42'dir. Katılımcıların yetersizlik türleri incelendiğinde; tüm çalışmalarda katılımcıların almış oldukları OSB tanıları ile birlikte sahip oldukları ek yetersizlik türleri Tablo 2'de verilmiştir. İncelenen çalı̧̧malardaki toplam katılımcı sayısı 130'dur.

\section{Zeka puanı}

Çalışmaların yalnızca birinde katılımcıların zeka puanlarına yer verilmiş ve çalışmadaki tüm katılımcıların zeka puanlarının 85-115 arasında olduğu belirtilmiştir.

\section{Problem davranışlar}

Katılımcı özellikleri olarak problem davranışlar değerlendirildiğinde; yalnızca iki çalışmada problem davranışların belirtildiği görülmüş ve bu davranışların neler olduğu Tablo 2'de sıralanmıştır. Holm ve aradaşlarının (2014) çalışmasında problem davranışlar yerine ailelerin çocuklarında görmek istedikleri hedef davranışlar olarak listeme yapılmış; Fung’un (2017) çalışmasında ise katılımcıların yalnızca "olumsuz davranışlar" sergiledikleri belirtilmiştir.

\section{Yöntemsel özellikler}

Yöntemsel özelliklere ilişkin bulgular Tablo 3’te görüldüğü gibi değerlendirilmiş ve analiz edilirken araştırma modeli, bağımlı değişken, bağımsız değişken, hayvan özellikleri, süre, ortam, uygulayıcı, sosyal geçerlik-kalıcılık-genelleme-güvenirlik ve sonuç olmak üzere dokuz ayrı kategoride ele alınmıştır.

\section{Araştırma modeli}

İncelenen çalışmaların üçünde $A B$ modeli, üçünde $A B A$ modeli, bir çalışmada tekrarlanan ölçümler, bir çalışmada dönüşümlü uygulamalar, iki çalışmada çoklu başlama modeli kullanılmıştır. Bir çalışmada ise araştırmanın ABAC ve ACAB biçiminde iki farklı model kullanılarak desenlendiği belirtilmiştir.

\section{Bağımlı değişken}

Araştırmaların üçünde (Kršková ve ark. 2010, Grigore ve Rusu 2014, Fung 2017) hedef davranışlar sosyal/iletişim becerileridir. Martin ve Farnum'un (2002) çalışmasında bağımlı değişken olarak belirlenen davranışlar listelenmiş ve Tablo 3’te verilmiştir. Sams ve arkadaşlarının (2006) çalışmasında propriyoseptif, vestibüler fonksiyon, duyusal-motor çalışma, dil, sosyal etkileşim davranışları hedef davranışları oluşturmuştur. Viau'nun (2010) çalışmasında bağımlı değişken katılımcıların kortizol seviyesidir. Silva ve diğerlerinde (2011) de bağımlı değişkeni oluşturan davranışlar listelenmiş ve bu davranışlar Tablo 3'te verilmiştir. Kern’in (2011) çalışmasında bağımlı değişken katılımcıların duyusal profilleridir. Jenkins ve Reed'te (2013) bağımlı değişken genel davranışlar iken, Holm ve arkadaşlarının (2014) 
çalışmasında ailelerin çocukları için hedef olarak belirledikleri davranışlardır. Llambias ve ark.nın (2016) çalışmasında ise hedeflenen katılım davranışları, bağımlı değişkenleri oluşturmuştur.

\section{Bağımsız değişken}

Çalışmaların dördünde (Kern 2011, Jenkins ve Reed 2013, Holm ve ark. 2014, Llambias ve ark. 2016) at terapisi bağımsız değişkeni oluşturmuştur. Beş çalışmada ise (Martin ve Farnum 2002, Viau 2010, Silva ve ark. 2011, Grigore ve Rusu 2014, Fung 2017) terapi köpeği ile yapılan müdahaleler bağımsız değişkendir. Kršková ve arkadaşlarının (2010) çalışmasında kobay; Sams ve arkadaşlarının (2006) çalışmasında ise köpek, tavşan ve lama destekli sunulan bir program bağımsız değişkendir.

\section{Kullanılan hayvan özellikleri}

Araştırmaya dahil edilen çalışmaların dördünde (Kršková ve ark. 2010, Silva ve ark. 2011, Gigore ve Rusu 2014, Fung 2017) HDM'de kullanılan hayvanın özelliklerine yer verilmiştir. Bu çalışmalardan Kršková ve arkadaşlarının (2010) çalışmasında kobay, diğer üç çalışmada ise köpek kullanılmıştır. Hayvan özelliklerinin belirtilmediği dört çalı̧̧mada (Kern 2011, Jenkins ve Reed 2013, Holm ve ark. 2014, Llambias ve ark. 2016) HDM olarak at kullanılmış ve kullanılan atların özellikleri yerine "Binicilik Programları" tanıtılmıştır. Martin ve Farnum (2002) ve Sams ve arkadaşlarının (2006) çalışmalarında hayvan özelliklerine yer verilmezken, Viau'nun (2010) çalışmasında ise hayvanın yalnızca eğitimli olduğu bilgisi verilmiştir.

\section{Süre}

Müdahale programlarının kaç oturum ve ne kadar süre uygulandığı incelendiğinde, Martin ve Farnum (2002) ve Sams ve arkadaşlarının (2006) çalışmalarında hayvan destekli müdahale programının 15 hafta uygulandığı; Martin ve Farnum'un (2002) çalışmasında 15'er dakikadan 45 oturum, Sams ve arkadaşlarının (2006) çalışmasında ise ortalama 28.5 dakika süren 2-12 oturum uygulandığı bilgisi verilmiştir. Kršková ve arkadaşları (2010) ile Grigore ve Rusu'nun (2014) çalı̧̧malarında ise uygulamanın 10 hafta sürdüğü; Kršková ve ark.'nın (2010) çalışmasının 240 dakikalık 10 oturumdan oluştuğu, Grigore ve Rusu'nun (2014) çalışmasında ise üç ayrı katılımcıya 15 dakikalık farklı oturum sayısı (haftada 2/3/3) uygulandığı belirtilmiştir. Üç çalışmanın (Viau, 2010, Silva ve ark. 2011, Holm ve ark. 2014) ise müdahale uygulama süreleri 4-6 haftadan oluşmaktadır. Bunlardan Viau'nun (2010) çalışmasında oturum sayısı ve uzunluğu hakkında bilgi verilmezken; Silva ve arkadaşlarının (2011) çalışmasında 45’er dakikadan altı oturum, Holm ve arkadaşlarının (2014) çalışmasında ise her katılımcıya dört hafta boyunca 30-45 dakikalık ayrı sayıda oturum (haftada 1/3/5) yapıldığı bilgisi verilmiştir. Jenkins ve Reed’in (2013) çalışmasında uygulanan müdahale programının oturum sayısı verilmemiş, 60 dakikalık oturumların dokuz hafta uygulandığı görülmüştür. Kern'de (2011) 24 hafta 60 dakikalık 24 oturum uygulandığ1; Llambias ve arkadaşlarının (2016) çalışmasında oturum sayısı ve süresinin verilmediği, grafiklerden müdahalenin 26 Temmuz - 23 Kasım tarihleri arası uygulandığı ve oturum uzunluklarının 
45-60 dakika olduğu görülmüştür. Son olarak Fung'un (2017) çalışmasında 20'şer dakikalık 23 oturum uygulandığı belirtilmiştir. Katılımcılara uygulanan müdahalelerden en kısa müdahale programı süresinin, oturum sayıları da dikkate alınarak, dört hafta olduğu (Viau, 2010); en uzun müdahale programı süresinin ise, yine oturum sayıları dikkate alınarak, 15 hafta (45 oturum) olduğu (Martin ve Farnum 2002) saptanmıştır.

\section{Ortam}

İncelenen araştırmalarda köpek veya kobay kullanılarak uygulanan hayvan destekli müdahalelerin (Martin ve Farnum 2002, Kršková ve ark. 2010, Silva ve ark. 2011, Grigore ve Rusu 2014,Fung 2017) okulda veya tedavi merkezinde uygulandığı; at kullanılarak uygulanan müdahalelerin (Kern 2011, Jenkins ve Reed 2013, Holm ve ark. 2014, Llambias ve ark. 2016) ise paralel olarak binicilik merkezinde uygulandığ1 görülmektedir. Köpek kullanılarak uygulanan müdahalelerden yalnızca Viau'da (2010) ortam olarak "ev" tercih edilmiştir. Sams ve arkadaşları (2006) ise lama, köpek ve tavşan kullanmış ancak araştırmacılar yine de ortam olarak okulu tercih etmişlerdir.

\section{Uygulayıcı}

Araştırmalar uygulayıcı değişkeni açısından incelendiğinde, dördünde (Martin ve Farnum 2002, Sams ve ark. 2006, Grigore ve Rusu 2014, Fung 2017,) terapistin, üçünde (Kern 2011, Jenkins ve Reed 2013, Holm ve ark. 2014) binici eğitmeninin, bir çalı̧mada (Kršková ve ark. 2010) öğretmenlerin; birinde (Llambias ve ark. 2016) hem terapist hem binici eğitmeninin, bir diğer çalışmada (Silva ve ark. 2011) ise psikoloğun uygulayıcı olduğu görülmektedir. Viau'nun (2010) çalı̧̧masında ise uygulayıcıya yönelik bilgi verilmemiştir.

\section{Sosyal geçerlik-kalıcılık-genelleme-güvenirlik}

İncelemeye dahil edilen 11 araştırmadan yalnızca bir araştırmada (Llambias ve ark. 2016) sosyal geçerlik verilerine yönelik bilgi sunulmuştur. Bu verilerin de öznel değerlendirme yöntemiyle toplandığı belirtilmiştir. Yalnızca iki çalışmada (Llambias ve ark. 2016, Fung 2017) kalıcılık verileri toplanmış ve araştırmalarda uygulanan müdahale etkilerinin kalıcı olduğu görülmüştür. Genelleme verilerine yer verme açısından çalışmalar incelendiğinde, üç çalışmada (Jenkins ve Reed 2013, Holm ve ark. 2014, Llambias ve ark. 2016) genelleme verilerine yer verilmiş ve araştırmalarda uygulanan müdahale etkilerinin genellendiği saptanmıştır. Güvenirlik verileri ise yalnızca iki çalışmada (Kršková ve ark. 2010, Viau 2010) verilmemiştir.

\section{Çalışmalarda ulaşılan sonuçlar}

Araştırma dahilinde incelenen 11 çalışma ulaşılan sonuçlar açısından değerlendirildiğinde, bir çalışma (Jenkins ve Reed 2013) dışında tüm çalışmalarda kullanılan hayvan destekli müdahalenin hedef becerilerde olumlu etki yarattığ 1 ve gelişim yaşandığı görülmüştür.Jenkins ve Reed'in (2013) çalı̧̧masında ise terapötik ata binmenin OSB'li çocukların davranışları üzerindeki etkileri incelenmiş; araştırma sonucunda terapötik ata binmenin katılımcı 
isteği, görev dışı davranış, problem davranış, uyumluluk veya dil (spontane başlangıçlar ve başlangıçlara verilen yanıtlar) üzerinde merkez temelli faaliyetler ve ev gözlemleri sırasında klinik olarak önemli etkiler yaratmadığı gözlenmiştir. Araştırmada zaman çizelgesinden elde edilen bulgular, terapinin bağımlı değişken üzerindeki performansı iyileştirmek için etkili bir müdahale olmadığını göstermiştir.

\section{Tartışma}

Bu çalışmanın amacı; 2000-2019 yılları arasında OSB olan çocuklara HDM aracılığıyla sunulan uygulamaların etkisini tek-denekli araştırma modelleriyle sınayan çalışmaları demografik, yöntemsel ve bulgu değişkenleri açısından inceleyerek kapsamlı bir betimsel analiz yapmak, var olan durumun niteliğini ortaya koyarak gelecek araştırmalara katkıda bulunmak ve OSB için HDM'lerin bilimsel dayanaklı uygulamalar kapsamındaki durumunu değerlendirmektir. Bu amaç doğrultusunda ulusal ve uluslararası alanyazında yayımlanan araştırmanın dahil etme ölçütlerini karşılayan 11 çalışma, farklı değişkenler açısından incelenerek betimlenmiştir. İncelenen 11 araştırma katılımcıların yaşları açısından değerlendirildiğinde, tüm çalışmalarda 3-14 yaş arası katılımcılarla çalışıldığı görülmektedir. Bunun araştırmalarda çalışılan becerilerin genellikle iletişim ve sosyal etkileşim becerileri olmasından kaynaklandığı veya bu yaş grubunun çevre ile etkileşime geçiş, arkadaşlık vb. gibi duygular ile duyular açısından açık, gelişme aşamasında bir dönem (Gander ve Gardiner 2015) olduğundan kaynaklandığı düşünülebilir. O’Haire'nin (2013) ve Srinivasan ve arkadaşlarının (2018) derleme çalışmalarında da incelenen araştırmalardaki katılımcı yaşlarının aynı yaş aralığında olduğu, O’Haire'nin (2013) incelediği çalışmalardan yalnızca iki çalışmanın (Keino ve ark. 2009, Gabriels 2012) sırasıyla 16 ve 17 yaşında katılımcı içerdiği görülmektedir. Alanyazında daha üst yaş gruplarıyla yapılan deneysel çalışmalara da rastlanmıştır. Örneğin; Wijker ve arkadaşları (2017), OSB olan 72 yetişkinin; Wijker ve ark. (2020) ise 18-60 yaş arası 53 yetişkinin katılımıyla araştırma yürütmüşler, HDM'nin OSB olan yetişkinlerde gelişme sağladığı ve kullanılabilecek bir uygulama olduğunu belirtmişlerdir. $\mathrm{Bu}$ araştırmalar gibi yetişkinlerin katılımıyla ve tek-denekli araştırma desenleriyle yürütülen araştırmaların yapılması, Erikson'a göre yetişkinlikte oluşabilecek rol karışıklığı, yalıtılmışlık, durgunluk, umutsuzluk gibi sorunlar (Gander ve Gardiner 2015) açısından da HDM'nin etkilerinin görülmesini sağlarken alanyazına katkı da sağlayacaktır. Cinsiyet açısından değerlendirildiğinde cinsiyet bilgileri verilmeyen çalışma (Sams ve ark. 2006) hariç diğger çalışmalardaki toplam 108 katılımcının 22'sinin kız, 86’sının erkek olduğu belirlenmiştir. Erkek katılımcı sayısının kızlara oranla daha fazla olması; OSB'nin erkeklerde görülme olasılığının kızlara oranla beş kat daha fazla olması ile açıklanabilir (NAC 2015).

Tanı ve zeka puanları açısından değerlendirildiğinde, 11 çalışmanın dördünde (Sams ve ark. 2006, Kršková ve ark. 2010, Llambias ve ark. 2016, Fung 2017) Otizm dışında ek engele sahip katılımcıların da olduğu; Otizm yoğunluğunun iki çalışmada (Grigore ve Rusu 2014, Fung 2017), zekâ puanlarının ise yalnızca bir çalı̧̧mada (Grigore ve Rusu 2014) verildiği görülmektedir. Oysa zeka puanı ve O’Haire'nin (2013) de belirttiği gibi Otizm şiddeti, uygulanan müdahalenin sonuçlarını etkilemiş olabileceğinden bu bilgilerin belirtilmemesi 
mevcut araştırmaların bir sınırlamasıdır. Gelecek araştırmalarda bu bilgilere de yer verilmesi, müdahalelerin etkileri konusunda daha fazla çıkarım yapılmasını sağlayabilir.

Çalı̧malardaki katılımcılar problem davranışları açısından değerlendirildiğinde, 11 çalışmanın ikisinde (Silva ve ark. 2011, Grigore ve Rusu 2014) problem davranışlara yönelik bilgi verildiği görülmüştür. Alanyazında konuyla ilgili yapılan derleme çalışmalarında da (O’Haire 2013, O’Haire ve ark. 2015, Srinivasan ve ark. 2018) katılımciların problem davranı̧̧ları inceleme kriterlerine alınmamıştır. Oysa problem davranışlara yer verilmesi, uygulanan müdahalenin bu davranı̧̧lar üzerindeki etkilerine veya bu davranışlara kaynaklık teşkil edebileceğine yönelik çıkarımlarda bulunulmasını sağlayabilir. Böylelikle ilerleyen çalışmalarda OSB olan katılımcıların aynı problem davranışları sergileme olasılıklarına karşı araştırmacılar önlem alabilir. Diğer yandan problem davranışlar, akran veya toplum etkileşimlerinde bireyin kabulünü, etkileşim başlatma olasılığını azaltmaktadır (American Psychological Association [APA] 2013). Bu nedenle özellikle sosyal becerilerin çalışıldığı araştırmalarda problem davranışlara yer verilmesi daha büyük önem arz etmektedir.

Çalışmalarda kullanılan araştırma modelleri incelendiğinde en fazla (Kršková ve ark. 2010, Kern 2011, Silva ve ark. 2011) AB ve (Viau 2010, Holm ve ark. 2014, Fung 2017) ABA modellerinin kullanıldığı görülmektedir. Ancak Gast ve Baekey’e (2014) göre AB deseni uygulamanın tam anlamıla etkili/etkisiz olduğunun belirlenmesine olanak tanımayan en basit tek-denekli araştırma desenidir (Rakap 2017). ABA modelinde de bağımlı ve bağımsız değişken arasındaki neden-sonuç ilişkisi güçlü şekilde ortaya konamamakta, sadece değişkenler arasındaki bağlantısal ilişkiden söz edilebilmektedir (Tekin-İftar 2018). Bu açıdan bakıldığında OSB olan bireylere HDM'nin etkilerini daha güçlü ortaya koyabilecek tek - denekli modellerle desenlenmiş araştırmalara ihtiyaç vardır. Horner ve ark.na (2005) göre bir uygulamaya bilimsel dayanak oluşturabilmesi için tek - denekli araştırmaların şu özelliklere sahip olmasını önermektedirler: Uygulamanın işevuruk tanımlanması, uygulamanın kimlerle-hangi ortamda/koşullarla yürütüleceğinin açıklanması, uygulamanın planlamaya bağlı kalınarak yürütülmüş olduğunun gösterilmesi, uygulamanın bağımlı değişkenlerdeki etkilerinin neden-sonuç ilişkisi şeklinde verilmesi, araştırma sonucunda kurulmuş olan neden-sonuç ilişkilerinin farklı araştırmalarla/araştırma ekipleriyle ve farklı katılımcılarla yinelenmesidir (Kırcaali-İftar 2018). Ancak AB modelleri ile başlama düzeyi ve uygulama verilerinin karşılaştırılmasına dayalı olarak bağımlı-bağımsız değişken arasındaki işlevsel ilişki ortaya konulamamaktadır (Tekin-İftar 2018). Alanyazındaki derleme çalışmalarında da (O’Haire 2013, O’Haire ve ark. 2015, Srinivasan ve ark. 2018) incelenen çalışmaların çoğunun deneysel desenle şekillendiği görülmektedir. HDM'nin henüz bilimsel dayanaklı uygulama olmaması (NAC 2015) göz önüne alındığında gelecekteki çalışmaların desenlenmesinde daha fazla tek-denekli araştırma deseni ve özellikle AB modeli dışındaki tek-denekli desenlerin kullanılması, HDM'nin bilimsel dayanaklarının daha güçlü temelde atılmasını sağlayabilir.

Bağımlı değişkenler açısından, incelenen 11 çalışmada en fazla (Martin ve Farnum 2002, Sams ve ark. 2006, Kršková ve ark. 2010, Grigore ve Rusu 2014, Llambias ve ark. 2016, Fung 2017) “sosyal etkileşim/iletişim”i kapsayan beceri ve davranışların bağımlı değişkenleri 
oluşturduğu görülmektedir. Bunu, otizmin yaygın belirtilerinin özellikle sosyal iletişim ve etkileşimdeki açıklar (DSM-5) olduğuna bağlayabiliriz. En az çalışılan bağımlı değişkenin ise [11 çalışmadan bir çalışmada (Viau 2010)] OSB olan bireylerin kortizol seviyeleri (stres hormonu salgılama düzeyi) olduğu görülmektedir. Bağımsız değişken bağlamında değerlendirildiğinde hayvan destekli müdahalelerde en fazla (Martin ve Farnum 2002, Viau 2010, Silva ve ark. 2011, Grigore ve Rusu 2014, Fung 2017) köpeklerin kullanıldığ1 görülmektedir. Bunu köpeklerin duygusal anlamda insanlara olan yakınlık ve bağımlılıklarına (Mey 2017, Çakıcı 2019) dolayısıyla OSB olan bireylere faydalarına (Mey 2017); sosyal, duygusal ve fizyolojik sağlık üzerinde olumlu etkiler yaratacak ve kaliteyi, yaşamı ve refahı iyileştirecek özelliklere sahip olmalarına (Delta Society 2019) bağlayabiliriz. HDM'de kullanılan hayvanların özellikleri açısından bakıldı̆̆ında yalnızca dört çalışmada (Kršková ve ark. 2010, Silva ve ark. 2011, Gigore ve Rusu 2014, Fung 2017) kullanilan hayvanın özelliklerine ilişkin bilgilerin yer aldığı görülmektedir. Bu çalışmalarda da bir çalışma dışında diğerlerinde köpek kullanılmıştır. Hayvan özelliklerinin belirtilmediği çalışmalarda ise at kullanıldığı ve kullanılan atların özellikleri yerine “Binicilik Programları”nın açıklamalarına yer verildiği görülmüştür.

İncelenen 11 çalışma, oturum sayıları ve süreleri dikkate alındığında, çalışma süreleri verilmeyen iki çalışma (Llambias ve ark. 2016, Fung 2017) dışında ortalama 10.7 hafta müdahale uygulandığı saptanmıştır. Yapılan alanyazın taramasında, HDM'nin uygulama süresine yönelik kesin bir bilgi olmadığı, uygulama sürelerinin araştırmalarda farklılık gösterdiği görülmüştür. O’Haire'nin (2013) çalışmasında da uç değerler olan 4-48 hafta uygulama süreleri bir yana, araştırmalarda ortalama 12.2 hafta müdahale uygulandığ saptanmı̧̧ ve uygulamaların genellikle kısa süreli olduğu belirtilmiştir. Gabriels ve arkadaşları (2015) ise, yaptıkları 10 hafta süreli uygulamanın etkilerini daha sonra aynı katılımcılarla uzun süreli (altı ay) etkileri açısından değerlendirmişler (Gabriels ve ark. 2018) ve araştırma sonucunda terapi grubundaki çocukların agresif davranışlar sergilemelerinde 0.1 düzeyinde azalma olduğunu, sosyal ve iletişim davranışlarında başta gösterdikleri önemli gelişmeleri sürdürdüklerini saptamışlardır.

Çalışmalar ortam ve uygulayıcı açısından değerlendirildiğinde, altı çalışmanın (Martin ve Farnum 2002, Sams ve ark. 2006, Kršková ve ark. 2010, Silva ve ark. 2011, Grigore ve Rusu 2014, Fung 2017) okul veya tedavi merkezinde; dört çalı̧̧manın binicilik merkezinde; bir çalışmanın (Viau 2010) ise evde uygulandığı görülmektedir. Çalışmaların dördünde (Martin ve Farnum 2002, Sams ve ark. 2006, Grigore ve Rusu 2014, Fung 2017) terapistin, üçünde (Kern 2011, Jenkins ve Reed 2013, Holm ve ark. 2014) binici eğitmeninin, bir çalı̧̧mada (Kršková ve ark. 2010) öğretmenlerin; birinde (Llambias ve ark. 2016) hem terapist hem binici eğitmeninin, bir diğer çalışmada (Silva ve ark. 2011) ise psikoloğun uygulayıcı olduğu görülmektedir. Bir çalışmada (Viau 2010) ise uygulayıcıya yönelik bilgi verilmemiştir. Okul veya tedavi merkezinde uygulanan HDM'in birinde (Kršková ve ark. 2010) kobay; birinde (Sams ve ark. 2006) lama-köpek-tavşan; diğer dört çalışmada ve evde uygulanan çalışmada ise köpek kullanılmış olması, bu hayvanların mevcut boyutlarına paralel olarak okulda/ tedavi merkezinde/evde kullanılmalarının uygun olabilmesine bağlanabilir. Ayrıca sınıfta 
köpeklerin kullanıldığ 1 programlar, öğrenci gelişimini teşvik etmek için okullara güçlü bir ek öğrenme aracı sağlayarak çocukların güvenini, sağlığını ve refahını geliştirmeyi amaçlayan; okuma ve yazma güçlüğü çeken ancak iyileştirici bir okuma programının parçası olmayan çocuklara odaklanan programlar olarak önemli özelliklere sahiptir (Delta Society 2019). Diğer dört çalışmada ise HDM olarak at kullanılmasından dolayı uygulamaların paralel olarak binicilik merkezinde ve binici eğitmeni eşliğinde uygulandığ1 görülmektedir. Bu yönden atların kullanıldığı HDM’in, binicilik merkezi ve binici eğitmeni mevcudiyetlerinin terapi köpekleri ve terapistlere oranla daha yaygin ve benzer özelliklere sahip olması dolayısıyla daha yinelenebilir uygulamalar olduğu söylenebilir (O’Haire 2013).

Sosyal geçerlik, kalıcılık ve genelleme verileri açısından ise her üç verinin incelenen çalışmalardan yalnızca birinde (Llambias ve ark. 2016) toplandığı ve sosyal geçerlik verilerinin öznel değerlendirme yaklaşımı ile toplandığı görülmüştür. Oysa kalıcılık sosyal geçerliği artırdığı gibi sosyal geçerlik de uygulamalı davranış analizi ilkelerinden uygulamalılık ilkesini ortaya koymakta, genelleme ise araştırmanın diş geçerliğini artırmaktadır. Ancak bu verilerin araştırmaların yalnızca birinde bulunması, alanyazında yapılan diğer derleme çalışmalarında da (O’Haire 2013, Davis ve ark. 2015) belirtildiği gibi araştırmaların yöntemsel zayıflıkla sınırlı olduklarını ve daha ayrıntılı araştırmalar ile ek sorgulamaya ihtiyaç olduğunu açıkça göstermektedir. Ayrıca özel gereksinimli çocuklara sunulan her hizmetin amacının onları akranlarına en yakın seviyede bağımsızlığa kavuşturmak olduğu göz önüne alındığında, yürütülen araştırmalarda öğretilen beceri ve davranışların amaca ne derecede hizmet ettiğinin saptanması; dolayısıyla sosyal karşılaştırma yaklaşımıyla sosyal geçerlik verilerinin toplanması önemlidir (Vuran ve Sönmez Kartal 2008). Güvenirlik verilerine yönelik değerlendirme yapıldığında_incelenen 11 çalışmadan iki çalışma dışında (Kršková ve ark. 2010, Viau 2010) tümünde güvenirlik verilerinin belirtildiği görülmektedir. Ancak gözlemciler arası güvenirlik verilerinin yanında uygulama güvenirliği verilerinin de belirtilmesi, uygulamaya yönelik daha net bilgiler elde edilmesini sağlayacak ve araştırma verilerinin daha güçlü ortaya koyulduğunu gösterecektir. Çünkü gözlemciler arası güvenirlik verileri, araştırmanın bağımlı değişkenine ilişkin güvenirlik analizini temsil ederken, uygulama güvenirliği verileri, araştırmanın bağımsız değişkenine ilişkin güvenirlik analizini temsil etmektedir (Tekin-İftar ve Kırcaali-İftar 2017, 94). Dolayısıyla her iki güvenirlik verilerine de yer verilmesi, uygulamalı davranış analizi ilkelerinden "teknolojik olmayı" sağlayacak ve araştırmaların farklı uygulamacılar tarafından uygulanmasına olanak taniyacaktır.

11 çalışma ulaşılan sonuçlar açısından değerlendirildiğinde, bir araştırma (Jenkins ve Reed 2013) dışında tüm araştırmalarda HDM'nin olumlu etkiler sağladığı, bağımlı değişkenler üzerinde gelişme/ilerleme kaydedildiği görülmüştür. Ulaşılan sonuçlar bakımından HDM'nin OSB olan bireylerde uygulanmasının umut vadettiği söylenebilir. Ancak araştırmalarda kısa dönemli uygulama sürelerinin de olması ve sosyal geçerlik/kalıcılık/ genelleme verilerinin toplanmaması, uygulamalarda soru işaretlerinin oluşmasına neden olmaktadır. Ayrıca bilimsel dayanak temelinin oluşması için daha ayrıntılı araştırmalarla sorgulanma ihtiyacını doğurmaktadır. HDM'nin OSB olan çocukların davranışları 
üzerindeki etkisini inceleyen araştırmaların derlendiği güncel bir çalışma olan Dimolareva ve Dunn (2020), uygulanan HDM dozajının HDM etki büyüklüğünde rol oynamasına yönelik az sayıda kanıt olduğunu belirterek, ilişkinin somut olarak kurulması için daha fazla veriye ihtiyaç olduğunu vurgulamışlardır.

\section{Sonuç}

Yapılan alanyazın taraması sonucunda incelenen çalı̧̧maların hepsinin yurt dişında yapıldığ1 görülmüştür. Konuyla ilgili Türkiye'de tek-denekli araştırma modeliyle desenlenmiş bir çalı̧̧maya rastlanmamıştır. Araştırmaya dahil edilen tüm araştırmaların bulguları incelendiğinde; HDM aracıllğıyla sunulan müdahalelerin bir çalışma dışında tüm çalışmalarda OSB olan çocukların hedef becerileri kazanmalarını sağladığı sonucuna ulaşılmıştır. Jenkins ve Reed (2013), terapötik ata binmenin OSB olan çocuklardaki performansı iyileştirmek için etkili bir müdahale olmadığını saptamışlardır. Ancak Cook ve Odom'un da (2013) belirttiği gibi bilimsel dayanaklı olsa dahi hiçbir uygulama her bir öğrenci için etkili değildir. HDM'nin ise henüz bilimsel dayanaklı uygulama olmadığı da göz önüne alındığında, incelenen 11 çalışmadan yalnızca birinde uygulamanın etkili bulunmaması, HDM kapsayan uygulamaların gelecek için umut vadettiği yönünde değerlendirilebilir.

Ulaşılan sonuçlara dayalı olarak ileriki araştırmalara yönelik öneriler şunlardır: Katılımcı özellikleri (OSB yoğunluğu, zeka puanları ve problem davranışları) daha iyi betimlenebilir ve katılımcı grubu olarak yetişkinlerle daha fazla çalışma yürütülebilir. Sosyal iletişim, etkileşim becerileri dışında farklı bağımlı değişkenleri ele alan çalışmalar yapılabilir. Araştırmalarda kullanılan hayvanların özelliklerine ayrıntılı olarak yer verilebilir. Araştırmalar tek-denekli araştırma modellerinden $\mathrm{AB}$ ve ABA desenleri dışında deneysel kontrol açısından daha güçlü tek-denekli araştırma modelleriyle desenlenebilir. Araştırmaların, katılımcı özellikleri, başlama düzeyi ve uygulama evresinin daha ayrıntılı ve açık bir biçimde rapor edildiği yinelenebilir özellikte raporlaştırıldı̆̆ı araştırmalar yapılabilir.

\section{Kaynaklar}

Akkuş A, Köse E, Erdoğan M, Taşpınar B, Taşpınar, F (2018) 0tizm Spektrum Bozukluğunda evcil hayvan desteği. Izmir Democracy University Health Sciences Journal, 1(3):34-42.

Allen K, Blascovich J, Mendes WB (2002) Cardiovascular reactivity and the presence of pets, friends, and spouses: the truth about cats and dogs. Psychosom Med, 64:727-39.

American Psychiatric Association (2013) Diagnostic and Statistical Manual of Mental Disorders, $5^{\text {th }}$ edition. Washington DC, American Psychiatric Association.

Anderson K, Olson M (2006) The value of a dog in a classroom of children with severe emotional disorders. Anthrozoös, 19:35-49.

Barak Y, Savorai 0, Mavashev S, Beni A (2001) Animal assisted therapy for elderly schizophrenic patients: A one-year controlled trial. Am J Geriatr Psychiatry, 9:439-442.

Barton Behravesh C (2017) Power of the pet: Pets enrich our lives. https://www.huffpost.com/entry/power-of-the-pet-pets-enrichour-lives_b_5908a7abe4b084f59b49fcf4 (Accessed 11.09.2020).

Çakıı A (2019) Evcil hayvan beslemenin insan sağlığı üzerindeki olumlu etkileri. Atlas Journal, 5(20):518-528.

Casciotti D, Zuckerman D (2020) The Benefits of Pets for Human Health. Washington DC, National Center for Health Research.

Cevizci S, Erginöz E, Baltaş Z (2009a) Ruh sağlığının iyileştirilmesinde destek bir tedavi yaklaşımı: Hayvan destekli tedavi. Nobel Medicus, 5:4-9. 
Cevizci S, Erginöz E, Baltaş Z (2009b) İnsan sağlığının iyileştirilmesine yönelik hayvan destekli tedaviler. TAF Prev Med Bull, 8:263-272. Cook BG, Odom SL (2013). Evidence-based practices and implementation science in special education. Except Child, 79:135-144.

Davis TN, Scalzo R, Butler E, Stauffer M, Farah YN, Perez S et al. (2015) Animal assisted interventions for children with autism spectrum disorder: A systematic review. Educ Train Autism Dev Disabil, 50:316-329.

Delta Society (2019) https://www.deltasociety.com.au/ (Accessed 2.03.2020).

Demiralay Ş, Keser I (2019) Ruh sağlığını koruma ve iyileştirmede hayvan destekli uygulamaların kullanımı. Mediterranean Journal of Humanities, 9:219-224.

Dimolareva M, Dunn TJ (2020) Animal-Assisted Interventions for school-aged children with Autism Spectrum Disorder: A meta-analysis. J Autism Dev Disord, doi: 10.1007/s10803-020-04715-w.

Edwards NE, Beck AM (2002) Animal-assisted therapy and nutrition in Alzheimer's disease. West J Nurs Res, 24:697-712.

Elitok B (2017) Otizmin tedavisinde hayvanların rolü. Dicle Üniversitesi Veterinerlik Fakültesi Dergisi, 10:163-167.

Esposito L (2011) Introduction. In Animals in Our Lives: Human-Animal Interaction in Family, Community, and Therapeutic Settings. (Eds. P McCardle, S McCune, JA Griffin, L Esposito, LS Freund): 1-5. Baltimore, Brookes Publishing.

Fine H (2015) Handbook on Animal-Assisted Therapy: Foundations and Guidelines for Animal-Assisted Interventions. Cambridge, Academic Press.

Friedmann E, Katcher AH, Lynch JJ, Thomas SA. (1980) Animal companions and one year survival of patients after discharge from a coronary care unit. Public Health Rep, 95:307-312.

Friedmann E, Son H (2009) The human-companion animal bond: How humans benefit. Vet Clin North Am Small Anim Pract, 39:293-326.

Fung SC (2017) An observational study on canine-assisted play therapy for children with autism: Move towards the phrase of manualization and protocol development. Glob J Health Sci, 9(7):67-86.

Gabriels RL, Agnew JA, Holt KD, Shoffner A, Zhaoxing P, Ruzzano S et al. (2012) Pilot study measuring the effects of therapeutic horseback riding on school-age children and adolescents with autism spectrum disorders. Res Autism Spectr Disord, 6:578-588.

Gabriels RL, Pan Z, Dechant B, Agnew JA, Brim N, Mesibov G. (2015) Randomized controlled trial of therapeutic horseback riding in children and adolescents with autism spectrum disorder. J Am Acad Child Adolesc Psychiatry, 54:541-549.

Gabriels RL, Pan Z, Guérin NA, Dechant B, Mesibov G (2018) Long-term effect of therapeutic horseback riding in youth with autism spectrum disorder: a randomized trial. Front Vet Sci, 5:156.

Gander MJ, Gardiner HW (2015) Çocuk ve Ergen Gelişimi (Çeviri A Dönmez, N Çelen). Ankara, İmge Kitabevi.

Gee NR, Harris SL, Johnson KL (2007) The role of therapy dogs in speed and accuracy to complete motor skills tasks for preschool children. Anthrozoos, 20:375-386.

Griffin JA, Mccune S, Maholmes V, Hurley K (2010) Human-animal interaction research: An introduction to issues and topics. In How Animals Affect Us: Examining The Influence of Human-Animal Interaction on Child Development and Human Health. (Eds P McCardle, S McCune, JA Griffin, V Maholmes): 3-9. Washington, American Psychological Association.

Grigore AA, Rusu AS (2014) Interaction with a therapy dog enhances the effects of social story method in autistic children. Soc Anim, 22:241-261.

Hajar R (2015) Animal-assisted therapy. Heart Views, 16(2):70-71.

Headey B (1999) Health benefits and health cost savings due to pets: Preliminary estimates from an Australian national survey. Soc Indic Res, 47:233-243.

Herzog H (2011) The Impact of pets on human health and psychological well-being: Fact, fiction, or hypothesis? Curr Dir Psychol Sci, 20:236-239.

Holm MB, Baird JM, Kim YJ, Rajora KB, D'Silva D, Podolinsky L et al. (2014) Therapeutic horseback riding outcomes of parent-identified goals for children with autism spectrum disorder: an ABA' multiple case design examining dosing and generalization to the home and community. J Autism Dev Disord, 44:937-947.

House JS, Landis KR, Umberson D (1988) Social relationships and health. Science, 24:540-544.

Human Animal Bond Research Institute-Habri (2020) The pet effect. https://habri.org/the-pet-effect/ (Accessed 29.05.2020).

Jenkins SR, Reed FD (2013). An experimental analysis of the effects of therapeutic horseback riding on the behavior of children with autism. Res Autism Spectr Disord, 7:721-740.

Jessen J, Cardiello F, Baun MM (1996) Avian companionship in alleviation of depression, loneliness, and low morale or older adults in skilled rehabilitation units. Psychol Rep, 78:339-348. 
Karayağiz-Muslu G, Conk Z (2011) Hayvan destekli uygulamalar ve çocuklarda kullanımı. Dokuz Eylül Üniversitesi Hemşirelik Yüksekokulu Elektronik Dergisi, 4:83-88.

Katcher AH, Wilkins GG (1998) Animal-assisted therapy in the treatment of disruptive behavior disorder in childhood. In The Environment and Mental Health: A Guide for Clinicians. (Ed. A Lundberg):193-204. Mahwah, NJ, Lawrence Erlbaum Associates.

Keino H, Funahashi A, Keino H, Miwa C, Hosokawa M, Hayashi Y et al. (2009) Psycho-educational horseback riding to facilitate communication ability of children with pervasive developmental disorders. J Equine Sci, 20(4):79-88.

Kern JK, Fletcher CL, Garver CR, Mehta JA, Grannemann BD, Knox KR et al. (2011) Prospective trial of equine-assisted activities in autism spectrum disorder. Altern Ther Health Med, 17(3):14-20.

Kircaali-iftar G (2018) Tek denekli araştırmaların tarihçesi. In Eğitim ve Davranış Bilimlerinde Tek Denekli Araştırmalar. (Ed E Tekiniftar):1-10. Ankara, Anı Yayıncillk.

Kršková L, Talarovičová A, Olexová L (2010) Guinea pigs-Th e "Small Great" therapist for autistic children, or: Do guinea pigs have positive effects on autistic child social behavior? Soc Anim, 18:139-151.

Kruger KA, Serpell JA (2010) Animal-assisted interventions in mental health: definitions and theoretical foundations. In Handbook on Animal-Assisted Therapy: Theoretical Foundations and Guidelines for Practice. (Ed AH Fine): 33-48. New York, Academic Press.

Kwon S, Sung IY, Ko EJ, Kim HS (2019) Effects of therapeutic horseback riding on cognition and language in children with Autism Spectrum Disorder or intellectual disability: A preliminary study. Ann Rehabil Med, 43:279-288.

Levine GN et al. (2013), Pet ownership and cardiovascular risk: a scientific statement from the American Heart Association. Circulation, 127:2353-2363.

Llambias C, Magill-Evans J, Smith V, Warren S (2016) Equine-assisted occupational therapy: Increasing engagement for children with autism spectrum disorder. Am J Occup Ther, 70(6):7006220040p1-7006220040p9.

Lodge DJ, Grace AA (2012) Divergent activation of ventromedial and ventrolateral dopamine systems in animal models of amphetamine sensitization and schizophrenia. Int J Neuropsychopharmacol, 15:69-76.

Martin F, Farnum J (2002) Animal-Assisted Therapy for children with pervasive developmental disorders. West J Nurs Res, 24:657-670.

McNicholas J, Gilbey A, Rennie A, Ahmedzai S, Dono JA, Ormerod E (2005) Pet ownership and human health: A brief review of evidence and issues. BMJ, 331:1252-1254.

Mey SC (2017) Animal Assisted Therapy for children with autism. Int J Child Dev Ment Health, 5:29-42.

Morrison ML (2007) Health benefits of Animal-Assisted Interventions. Complement Health Pract Rev, 12:51-62.

Nafsted P, Magnus P, Gaader PI, Jaakola JJK (2001) Exposure to pets and atopy-related diseases in the first 4 years of life. Allergy, 56:307-312.

National Autism Center (NAC) (2019) https://www.nationalautismcenter.org/news/ (Accessed 7.09.2019).

National Center for Emerging \& Zoonotic Infectious Diseases (NCEZID) (2019) About pets \& people. https://www.cdc.gov/healthypets/ health-benefits/index.html (Accessed 2.1.2020).

National Institutes of Health (NIH) (2018) The Power of pets health benefits of human-animal interactions. News in Health, February 2018.

Nimer J, Lundahl B (2007) Animal-assisted therapy: A meta-analysis. Anthrozoos, 20:225-38.

O'haire ME (2013) Animal-assisted intervention for autism spectrum disorder: A systematic literature review. J Autism Dev Disord, 43:1606-1622.

0'haire ME (2017) Research on animal-assisted intervention and autism spectrum disorder 2012-2015. Appl Dev Sci, 21:200-216.

0 'haire ME, Guérin NA, Kirkham AC, Daigle CE (2015) Animal-assisted intervention for autism spectrum disorder. HABRI Central Briefs: Animal-Assisted Intervention for Autism Spectrum Disorder, 1-8.

Odendaal JS (2000) Animal-assisted therapy - Magic or medicine? J Psychosom Res, 49:275-280.

Ownby DR, Johnson CC, Peterson EL (2002) Exposure to dogs and cats in the first year of life and risk of allergic sensitization at 6 to 7 years of age. JAMA, 288:963-972.

Özkul T (2014) Türkiye'de hayvan destekli terapi uygulamalarindan örnekler. IV. National Symposium of the History of Veterinary Medicine and Professional Ethics, 21-23 Mayis 2014.

Pan Z, Granger DA, Guérin NA, Shoffner A, Gabriels RL (2019) Replication pilot trial of therapeutic horseback riding and cortisol collection with children on the autism spectrum. Front Vet Sci, 5:312.

Parker $G$ et al. (2010) Survival following an acute coronary syndrome: A pet theory put to the test. Acta Psychiatr Scand, 121:65-70.

Purewal R, Christley R, Kordas K, Joinson C, Meints K, Gee N, et al. (2017) Companion animals and child/adolescent development: A systematic review of the evidence. Int J Environ Res Public Health, 14:234. 
Qureshi Al, Memon MZ, Vazquez G, Suri MF (2009) Cat ownership and the risk of fatal cardiovascular diseases. Results from the second national health and nutrition examination study mortality follow-up study. JVasc Interv Neurol, 2:132-135.

Rakap S (2017) Tek denekli deneysel araştırma yöntemleri. In Uygulamalı Davranış Analizi. (Eds D Erbaş, Ş Yücesoy Özkan): 156-165. Ankara, Pegem Akademi.

Sams MJ, Fortney EV, Willenbring S (2006) Occupational therapy incorporating animals for children with autism: A pilot investigation. Am J 0ccup Ther, 60:268-274.

Serpell JA (1991) Beneficial effects of pet ownership on some aspects of human health and behaviour. J R Soc Med, 84:717-720.

Serpell JA (2006) Animal-assisted interventions in historical perspective. In Handbook on Animal-Assisted Therapy: Theoretical Foundations and Guidelines for Practice. (Ed AH Fine): 3-20. San Diego, Academic Press.

Silva K, Correia R, Lima M, Magalhães A, De Sousa L (2011) Can dogs prime autistic children for therapy? Evidence from a single case study. J Altern Complement Med, 17:655-659.

Souza-Santos C, Dos Santos JF, Azevedo-Santos I, Teixeira-Machado L (2018) Dance and equine-assisted therapy in Autism Spectrum Disorder: Crossover randomized clinical trial. Clin Neuropsychiatry, 15:284-290.

Srinivasan SM, Cavagnino DT, Bhat AN (2018) Effects of equine therapy on individuals with autism spectrum disorder: A systematic review. Rev J Autism Dev Disord, 5:156-175.

Tekin-Iftar E (2018) AB modelleri. In Eğitim ve Davranış Bilimlerinde Tek Denekli Araştırmalar (Ed. E Tekin-Iftar): 155-180. Ankara, Anı Yayıncilık.

Tekin-Iftar E, Kırcaali-Iftar G (2017) Özel Eğitimde Yanlışsız Öğretim Yöntemleri. Ankara, Vize Yayıncılık.

Tohum Otizm Vakfı (TOV) (2019) Ulusal Standartlar Projesi: Bulgular ve Sonuçlar Özet Raporu 2019 İstanbul, Tohum Otizm Vakfı.

Vanfleet R, Faa-Thompson T (2010) The case for using animal assisted play therapy. Br J. Play Therapy, 6:4-18.

Viau R, Arsenault-Lapierre G, Fecteau S, Champagne N, Walker CD, Lupien S. (2010) Effect of service dogs on salivary cortisol secretion in autistic children. Psychoneuroendocrinology, 35:1187-1193.

Walters Esteves S, Stokes T. (2008) Social effects of a dog's presence on children with disabilities. Anthrozoos, 21:5-15.

Wanser SH, Vitale KR, Thielke LE, Brubaker L, Udell MA (2019) Spotlight on the psychological basis of childhood pet attachment and its implications. Psychol Res Behav Manag, 12:469-479.

Wells D (2011) The value of pets for human health. The Psychologist, 24:172-176.

Wells DL (2009) The effects of animals on human health and wellbeing. J Soc Issues, 65(3):523-543.

Wijker C, Leontjevas R, Spek A, Enders-Slegers MJ (2020) Effects of dog assisted therapy for adults with autism spectrum disorder: An exploratory randomized controlled trial. J Autism Dev Disord, 50:2153-2163.

Wijker C, Spek AA, Leontjevas R, Verheggen T, Enders-Slegers MJ (2017) The effectiveness of Animal Assisted Therapy in adults with Autism Spectrum Disorder: Study protocol for a randomized controlled trial. Autism 0pen Access, 7:5.

Wolery M, Bailey DB, Sugai GM (1988) Effective Teaching: Principles and Procedures of Applied Behavioral Analysis with Exceptional Students. Boston, Allyn and Bacon.

Wright JD, Kritz-Silverstein D, Morton DJ, Wingard DL, Barrett-Connor E (2007) Pet ownership and blood pressure in old age. Epidemiology, 18:613-618.

Zasloff RL, Hart LA, Dearmond H (1999) Animals in elementary school education in California. J Appl Anim Welf Sci, 2:347-357.

ZORO (2017) Eğitime hayvan entegrasyonu kılavuz kitabı (Animal integration in the educational programme-ZORO) (2017) Erasmus+ Projesi.

Yazarların Katkıları: Yazarlar çalışmaya önemli bir bilimsel katkı sağladıklarını ve makalenin hazırlanmasında veya gözden geçirilmesinde yardımcı olduklarını kabul etmişlerdir.

Danışman Değerlendirmesi: Dış bağımsız.

Çıkar Çatışması: Yazarlar çıkar çatışması bildirmemiştir.

Finansal Destek: Yazarlar bu çalışma için finansal destek almadığını beyan etmiştir.

Authors Contributions: The authors attest that they have made an important scientific contribution to the study and have assisted with the drafting or revising of the manuscript.

Peer-review: Externally peer-reviewed.

Conflict of Interest: No conflict of interest was declared by the authors.

Financial Disclosure: The authors declared that this study has received no financial support. 